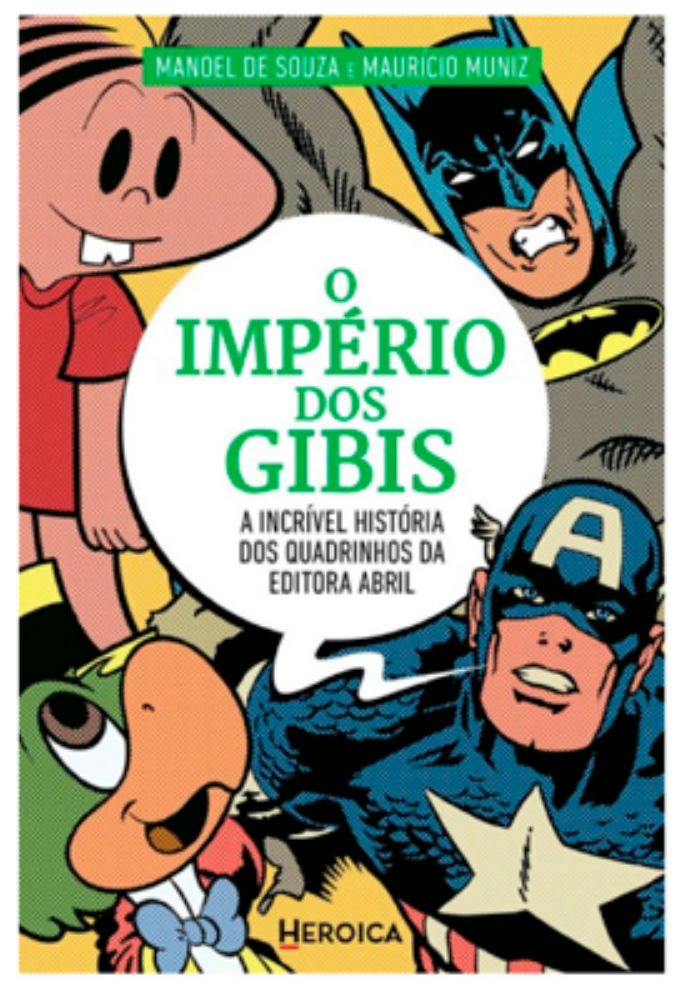

\title{
A grande fábrica de quadrinhos
}

\author{
Roberto Elisio dos Santos ${ }^{1}$ \\ Observatório de Histórias em Quadrinhos da ECA-USP
}

Durante sete décadas, a Editora Abril, de São Paulo, foi responsável pela publicação de quadrinhos no Brasil, de início timidamente, mas atingindo grandes tiragens e uma quantidade crescente de títulos a partir da década de 1970 até aos anos 1990, além de produzir farto material feito por artistas locais. Ao lado de pequenas casas publicadoras (Outubro, Trieste, GEP, Saber, Codecri, Circo, Press, Grafipar, entre outras), grandes empresas editoriais atuaram no país durante décadas (Globo, EBAL e Abril, por exemplo), criando comunidades de fãs e uma cultura relacionada às narrativas gráficas sequenciais.

\footnotetext{
${ }^{1}$ Doutor em Ciências da Comunicação e vice-coordenador do Observatório de Histórias em Quadrinhos da ECA-USP. Email: robelisio@yahoo.com.br. ORCiD: https://orcid.org/0000-0002-57675-4579.
} 
Para registrar a trajetória daquela que foi considerada a maior editora da América Latina, tendo colocado nos pontos de vendas mais de 17 mil edições (segundo o site Guia dos Quadrinhos ${ }^{2}$ ), os jornalistas Manoel de Souza e Maurício Muniz realizaram uma extensa pesquisa e muitas entrevistas, que resultou no livro $O$ império dos quadrinhos: a incrivel história dos quadrinhos da Editora Abril, cuja publicação foi viabilizada por meio de projeto na plataforma de crowdfunding (ou financiamento coletivo) Catarse $^{3}$. Com mais de 400 páginas, a obra não é um trabalho acadêmico, mas um livro-reportagem que contém uma grande quantidade de informações, tanto de títulos que duraram décadas como os que tiveram poucas edições, que interessam aos fãs e a pesquisadores, principalmente de quadrinhos Disney e dos heróis da Marvel e da DC Comics.

A linguagem jornalística empregada pelos autores faz com que a leitura seja leve e rápida. Os depoimentos colhidos tratam das intrigas, brincadeiras e danças das cadeiras, formando um pano de fundo do cotidiano de uma grande empresa que teve nas histórias em quadrinhos sua principal fonte de renda, impactando as decisões editoriais, algumas que se provaram corretas e outras, equivocadas. Além disso, esses testemunhos põem em evidência artistas e editores que colaboraram com a consolidação e crescimento da editora Abril durante décadas, como o quadrinista e editor Waldyr Igayara, o roteirista e editor Cláudio de Souza (GONÇALO JÚNIOR, 2005) e o desenhista, roteirista e editor Primaggio Mantovi (CHINEN, 2014), além dos vários responsáveis pelos quadrinhos da Marvel e da DC. A obra também retrata a concorrência, nem sempre leal, de várias empresas que formaram o mercado editorial de histórias em quadrinhos no Brasil ao longo de meio século.

O livro esclarece vários pontos sobre a história da editora Abril, como sua fundação, oficialmente ocorrida em 1950 por Victor Civita. No entanto, a empresa foi criada no final dos anos 1940 por César Civita (GONÇALO JÚNIOR, 2005; SCARZANELLA, 2016). O empresário judeu italiano deixou seu país natal no final da década de 1930 devido à escalada de antissemitismo na Europa. Primeiro foi para Nova York e, em seguida, estabeleceu-se em Buenos Aires, onde fundou o Editorial Abril, responsável pelo lançamento da revista El Pato Donald em 1944, ao lado de publicações de quadrinhos feitos na Argentina. Preocupado com os rumos da política

\footnotetext{
${ }^{2}$ Disponivel em: http://www.guiadosquadrinhos.com/. Acesso em 19 ago. 2020.

${ }^{3}$ Disponivel em: https://www.catarse.me/. Acesso em 20 ago. 2020.
} 
naquele país, resolveu fundar uma empresa em São Paulo e, depois, convenceu seu irmão Victor a assumir o empreendimento.

Outra imprecisão corrigida pelos autores diz respeito à primeira publicação da editora Abril, que não foi O Pato Donald número 1 , de julho de 1950 , como foi difundido pelo próprio Victor Civita. Ainda nos anos 1940 foram lançadas diversas publicações originalmente feitas e publicadas na Argentina - sendo um exemplo Donald O Grande Goleador, o nono número da coleção Pequenos Grandes Livros, de 1948. Em maio de 1950 foi a vez de Raio Vermelho, que teve 53 edições e foi descontinuado em 1953, chegar às bancas brasileiras, dois meses antes dos quadrinhos Disney.

Os autores documentam, nos capitulos finais, as crises enfrentadas pela editora após a virada do milênio e a sua melancólica derrocada em 2018, apontando as causas internas e externas que culminaram com o encerramento das atividades dessa grande fábrica de quadrinhos, para o desalento de fãs, pesquisadores e colecionadores.

No final do livro, o leitor encontra, entre outras seções, um caderno em cores com imagens de capas e de quadrinhos publicados pela Abril, inclusive uma história inédita que deveria ter sido publicada na edição dos 50 anos da revista Pato Donald, na qual o pato, como repórter do jornal $A$ Patada, entrevista o empresário e publisher Roberto Civita. Há, também, diversas tabelas com o título das revistas, o ano de lançamento e de encerramento e o número total de edições de cada título, divididas por autor ou editora (Walt Disney, Hanna-Barbera, Walter Lantz, Mauricio de Sousa, Marvel Comics, DC Comics etc.). Acompanham o livro fichas com a reprodução de capas na frente e os dados sobre a publicação no verso e dois dossiês, um sobre a revista Capitão América e outro sobre o título Heróis da TV (com os personagens da Marvel) e dois infopôsteres dessas duas publicações, com desenhos novos feitos por artistas brasileiros.

\section{Referências}

CHINEN, Nobu. Primaggio Mantovi: o mestre de estilo versátil. Rio de Janeiro: Marsupial, 2014.

GONÇALO JÚNIOR. O Homem-Abril: Cláudio de Souza e a história da maior editora brasileira de revistas. São Paulo: Opera Graphica, 2005. 
SCARZANELLA, Eugenia. Uma editora italiana na América latina: O Grupo Abril: décadas de 1940 a 1970. Campinas: Editora da Unicamp, 2016.

SOUZA, Manuel de; MUNIZ, Maurício. O império dos gibis: a incrivel história dos quadrinhos da Editora Abril. São Paulo: Heroica, 2020. 